\title{
TRMM/PRバージョン7プロダクトの強い雨 HEAVY RAIN ESTIMATES IN TRMM/PR STANDARD PRODUCT VERSION 7
}

\author{
瀬戸心太 ${ }^{1} \cdot$ 井口俊夫 $^{2} \cdot$ 内海信幸 $^{3} \cdot$ 沖大幹 $^{4}$ \\ Shinta SETO, Toshio IGUCHI, Nobuyuki UTSUMI, and Taikan OKI \\ 1正会員＼cjkstart博士(工学) 東京大学生産技術研究所 (广153-8505 東京都目黒区駒場4-6-1) \\ 2非会員 Ph.D (独)情報通信研究機構 (广184-8795 東京都小金井市貫井北町4-2-1) \\ 3正会員 修士(工学) 東京大学生産技術研究所 (广153-8505 東京都目黒区駒場4-6-1) \\ 4正会員＼cjkstart博士(工学) 東京大学生産技術研究所 (广153-8505 東京都目黒区駒場4-6-1)
}

\begin{abstract}
The latest version of the TRMM (Tropical Rainfall Measuring Mission)/PR (Precipitation Radar) standard product (Version 7; V7) was recently released. This study focuses on heavy rain rate estimated in V7, which are more frequent than in the previous version (Version 6; V6). Surface reference technique is crucial for attenuation correction particularly of heavy rainfall, and becomes more reliable in V7, mainly because of ensemble of multiple SRT methods. Though the accuracy of clutter detection and the validity of $Z-R$ relations are carefully examined, there are still possible rain estimates with extremely heavy rate of more than $300 \mathrm{~mm} / \mathrm{h}$. As hourly rain rate, $300 \mathrm{~mm} / \mathrm{h}$ should be unexceptional, but the time scale of PR measurement may be shorter than 1 hour and these extremely heavy rain rate estimates should be investigated considering the time scale. Relations between heavy rain rates and surface temperature are analyzed with V7 and surface measurements. 99\% rain rates in V7 generally increase with the increase of daily surface temperature, though daily rain amount by gauges tends to decrease when daily surface temperature becomes higher than $25^{\circ} \mathrm{C}$, which implies different time scales between PR and gauge measurements.
\end{abstract}

Key Words : heavy rain, time scale, precipitation radar (PR), surface reference technique, C-C relation

\section{1.はじめに}

2011年7月，熱帯降雨観測衛星(TRMM)に搭載された 降雨レーダ(PR)の標準アルゴリズムがバージョン7(V7) に更新された ${ }^{1)}$. 1997年12月の観測開始以来のプロダク トもV7で再処理され公開済である.PRの観測期間は間 もなく14年に達し(原稿執筆時点)，2013年に運用開始予 定の後継センサである二周波降水レーダ(DPR) $)^{2}$ による観 測期間に切れ目なくつながることも十分期待できる. 将 来的には, 河川計画のための水文統計解析や気候変動影 響評価など長期的なデータを要する実務・研究において も，衛星観測が大きな役割を果たすことが期待される. そのためには, 観測精度のさらなる向上と, 衛星観測の 特性を活かした利用法の検討が重要と考える.

降水強度について, PRによる推定值を雨量計による 観測值と比較する際には，時間スケールに注意する必要 がある. PRの鉛直分解能は $250 \mathrm{~m} て ゙ あ り ，$ 雨滴の代表的 な落下速度を 1 ～ 5 /秒とすると，PRで観測された雨は， およそ1～5分程度かけて雨量計に蓄積されることになる. このことから, PRの降水強度推定の時間スケールは数
分のオーダーとみられる.ただし，PRと雨量計の観測 範囲が異なるため $(\mathrm{PR} は$ 直径約 $5 \mathrm{~km}$, 一般的な雨量計は 直径 $20 \mathrm{~cm}), \mathrm{PR}$ 観測範囲内における雨の非一様性を考 慮する必要がある．単一の積雲の代表的な大きさはPR の観測範囲と同オーダーで，その寿命は1時間程度であ ることを考えると, PRの降水強度推定の時間スケール は1時間を超えないと考えられる。

近年，社会的影響の大きい都市型水害においては，強 い雨の発生から河川・下水道の増水までの時間が短い. 短い時間スケールの降水強度の情報が得られるというこ とは，雨量計観測に対する衛星降水観測の利点であると 言える. 長期間データを蓄積することで，短時間降水強 度の極值についての情報を得ることも可能となる。

本論文では，PR V7を上記のような目的に活用寸るた めに重要となる, 短い時間スケールにおける強い雨の推 定精度について検討する. なお本論文では，下水道の整 備目標としてよく用いられる $50 \mathrm{~mm} / \mathrm{h}$ を超える雨を「強 い雨」として扱う，以下の2章では，V7の概要を説明し， 3章ではアルゴリズムの妥当性という視点から，V7の強 い雨を検証する，4章では，V7を用いた強い雨の特性に ついての解析の一例を示す. 


\section{V7ににおける降水強度推定}

\section{(1) 概要}

PRの標準アルゴリズム3)は，図-1に示すように，レー ダ反射因子の減衰補正と, 降水強度への変換の二つから なる. 減衰補正前のレーダ反射因子を $Z_{\mathrm{m}}$, 減衰補正後の レーダ反射因子を $Z_{\mathrm{e}}$ と書く，減衰補正には，表面参照法 4) と Hitschfeld-Bordan(HB)法5)を組み合わせたハイブリッ ド法が採用されている，表面参照法は，降雨によるパス 積算減衰量(PIA)の第一推定値として, 降雨のあるピク セルと降雨のないピクセル群の地表面後方散乱断面積の 差 $\left(\Delta \sigma^{0}\right)$ を計算する. $\mathrm{HB}$ 法は, 減衰係数 $k$ と $Z_{\mathrm{e}}$ の関係を, 式(1)のべき乗則で与えることで， $Z_{\mathrm{m}}$ から $Z_{\mathrm{e}}$ を解析的に得 る.

$$
k=\varepsilon \alpha_{0} Z_{\mathrm{e}}^{\beta}
$$

ここで， $\alpha_{0}$ および $\beta は ，$ 降水タイプ等に応じてあらかじ め決められている ${ }^{6}$ ， \&は鉛直一定な定数であり，HB法

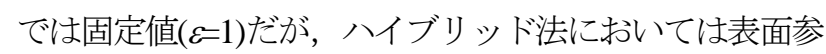
照法の情報を加えて修正される. 式(1)で得られた $k$ をパ ス全体で積分するとPIAの最終推定値が得られる．表面 参照法の信頼度が高い場合には，PIAの最終推定値は， 表面参照法による第一推定值に近くなる。一般に強い雨 の場合, 表面参照法の信頼度は高い.

降水強度 $R$ への変換には, 式(2)の関係が用いられる.

$$
R=a Z_{\mathrm{e}}^{b}
$$

係数 $a, b$ は, 降水タイプ等に依存するが6), 式(1)の $\alpha\left(=\varepsilon \alpha_{0}\right), \beta$ と整合性を持つように修正される7 . 寸なわち, 減衰補正の際に $\varepsilon か ゙$ 変化すると, $a, b$ も変化する. 対流性 で0 $0^{\circ}$ の液体降水の場合, 以下のようになる.

$$
\log _{10}(a)=-1.43+0.86 \times \log _{10}(\varepsilon)-1.12 \times\left\{\log _{10}(\varepsilon)\right\}^{2}
$$

$\log _{10}(b)=-0.19+0.098 \times \log _{10}(\varepsilon)+0.19 \times\left\{\log _{10}(\varepsilon)\right\}^{2}$

$\varepsilon か ゙$ 通常取りうる範囲では， $a, b は ， \varepsilon の$ 単調増加関数と なる. 寸なわち，同じ $Z_{\mathrm{e}} に$ 対して 8 が大きくなるほどRも 大きくなる．また， $Z_{\mathrm{e}}$ が10dB増えると，Rは10b倍になる ( $\varepsilon=1$ の場合, 約4.4倍).

\section{(2) V7ににおける変更点}

V7の一つ前のバージョン6(V6) $)^{8}$ は2004年に公開されて 以来，広く使われており，様々な検証が行われてきた9 陸上では，降水量を過小評価しているという指摘が多く あり ${ }^{10)}, \mathrm{V} 7$ でのアルゴリズム改良に反映された. 特に, 表面参照法について，大きな変更が加えられた。

表面参照法は, 地表面状態に依存寸るため, 陸上と海 上で異なる手法が用いられている，以下，陸上の場合を 説明する. V6では, 空間参照法(Forward処理) と時間参 照法の2種類の表面参照法があり，ピクセルごとに信頼 度の高い手法を選ぶ11)．特に時間参照法では，降水によ る表層土壤水分量増加の影響(土㙵水分効果と呼ぶ)を考 慮せずPIAを過小評価していること ${ }^{12)}$ ，また空間参照法

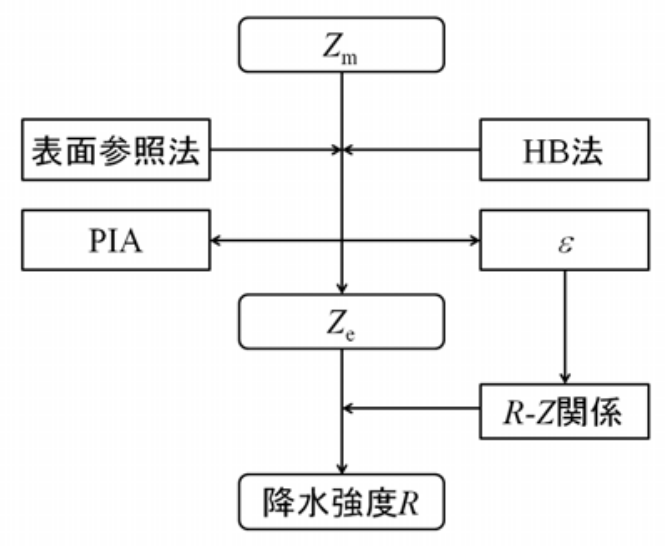

図-1＼cjkstart標準アルゴリズムの概略図

では土地被覆が大きく異なるピクセルを比較することに

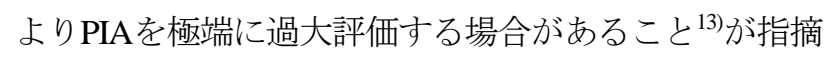
されている.

V7での表面参照法は，空間参照法(Forward処理), 同 (Backward処理), 時間参照法の3つがあり，それぞれの 信頼度の重みをつけた平均によりPIAの第一推定值を求 めている. 前述の問題を軽減するため, 空間参照法では 一定以上距離の離れたピクセルは参照しないようにして, さらに，参照ピクセルを直前の観測から探すForward処 理だけでなく直後の観測から探すBackward処理を加えた. 土壤水分効果については，V7の表面参照法でも十分説 明できていないと予想されたため, PIAの第一推定值に 一律 $0.5 \mathrm{~dB}$ 加えるという対策が行われている.

V7では，表面参照法以外にも，ピクセル内の非一様 性の導入, 固体降水・融解層における減衰量特性の鉛直 プロファイルの修正などが行われている.

\section{V7における強い雨}

この章では, V7のプロダクトにおける強い雨につい て，V6のプロダクトとの比較により，アルゴリズムの 改良の効果を検証する. 本論文の主な関心は陸上にある が，参考のために，表面参照法の精度が高いと考えられ る海上での結果も示す.

なお，本章の結果は，V7の公開前検証において行わ れたものであり，2000年1年間を対象に，V7については OAT(Operational Algorithm Test)プロダクトを用いている. OATと公開されている標準プロダクトの差異は, 非常に 小さい．結果の一部は速報されているが14)，本論文では, $100 \mathrm{~mm} / \mathrm{h}$ 超える非常に強い雨も含めて解析した結果を 示寸. 入射角依存性の問題については, 速報を参照され たい.

\section{(1) 強い雨の寄与}

降水強度の累積分布を，陸上および海上，V6および 
V7について，それぞれ示寸(図-2). 横軸の降水強度以下 の雨のみから算出された平均降水量を縦軸に示している. なお，降水強度推定值の上限は $300 \mathrm{~mm} / \mathrm{h}$ である．計算結 果が300 mm/hを超える場合は $300 \mathrm{~mm} / \mathrm{h}$ に修正されている。

陸上の場合, 総降水量(300mm/hまでの累積值)では, V7の方がV6より高いが，50mm/hまでの累積值では，V7 とV6はほぼ等しい，したがって，V7では，50mm/hを超 える強い雨の寄与が大きい，一方，海上では，総降水量 だけでなく50mm/hまでの累積值でもV7がV6より高い. 50mm/hを超える強い雨の寄与分について, V7とV6の差 の陸上での地域的分布を図-3に示寸．もともと降水量の 多い熱帯域を中心にV6よりV7で高くなっている．ただ し，島嶼部・沿岸部ではV6の方が高い地点も見られる。

\section{(2) 強い雨の要因}

2(1)での説明から分かるように，強い雨には， $Z_{\mathrm{e}}$ が高

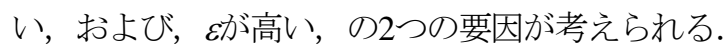

図-4に, 50mm/h〜300mm/hまでの強い雨について, $10 \mathrm{~mm} / \mathrm{h}$ ごとのビンに分類し, 地表面付近の $Z_{\mathrm{e}}(\mathrm{dB})$ の平均 值を示す． Eが一定と寸れば, $Z_{\mathrm{e}}(\mathrm{dB})$ の変化は, $\log R$ の変 化に比例することから，横軸は対数軸とした．図中の斜 めの直線は，代表的な変化率 $\left(Z_{\mathrm{e}}\right.$ が $10 \mathrm{~dB}$ 増えるとRは4.4 倍になる)に相当する．陸上・海上ともに，V6に比べて V7の方の変化率が高く,V7では代表的な変化率に近い. V7では, 強い雨の要因は高いZ滛にあると言える.

図-5には，図-4と同様の方法で，\&について示す，V6 では，強い雨ほど放高い傾向が見られるが，V7では， 降水強度と磵に明確な相関は見られない.V6での強

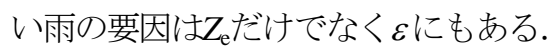

\section{(3) 強い雨の減衰補正}

V7での強い雨の要因であるZ $Z_{\mathrm{e}}$ 妥当性，すなわち減衰 補正の妥当性について検討寸る.V7での強い雨につい て，3種類の表面参照法による $\Delta \sigma^{0}$ を図-6に示寸，少な くとも $150 \mathrm{~mm} / \mathrm{h}$ 付近までは, 3 種類の $\Delta \sigma^{0}$ に大きな差は見 られない. 図-7には, この3種類の $\Delta \sigma^{0}$ から作成された PIAの第一推定值(青実線)とハイブリッド法の結果であ るPIAの最終推定值(青鎖線)を示す，最終推定值は，第 一推定值よりやや低くなる傾向にある.これは，HB法 で仮定する $k-Z$ 関係 $(\varepsilon=1)$ が必ずしも強い雨には適切でな いことを示唆している.

図-7には，比較のために，V6におけるPIAの第一推定 值(赤実線)と最終推定值(赤鎖線)も示してある.ただし， 図の横軸はV7における降水強度推定值である.すなわ ち，V6とV7をピクセルごとにマッチアップして，V7の 降水強度が50mm/h以上であったピクセルでのV6の推定 值について示している. 第一推定值は, V6とV7の間で ほとんど変わらないが，最終推定值は，V6ではV7より も低くなっている。 この理由として,V7では3種類の $\Delta \sigma^{0}$ を用いることにより，それらがよく一致する場合に

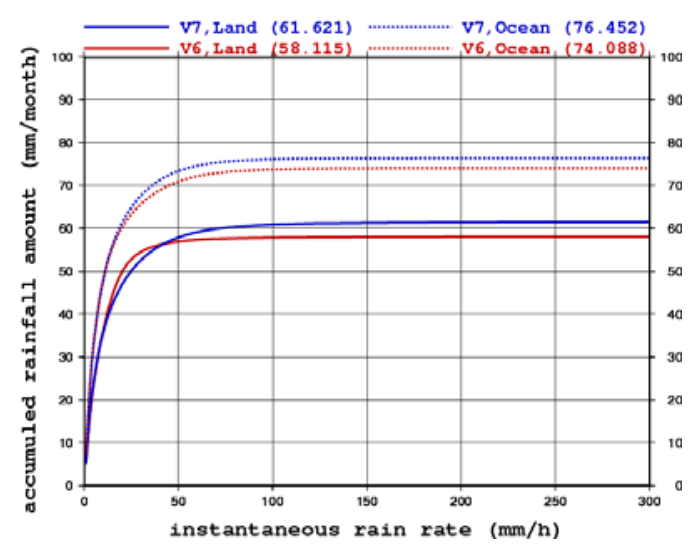

図-2 降水強度の累積分布. 青実線はV7陸上, 青点線はVV7 海上, 赤実線はV6陸上, 赤点線はV6海上.

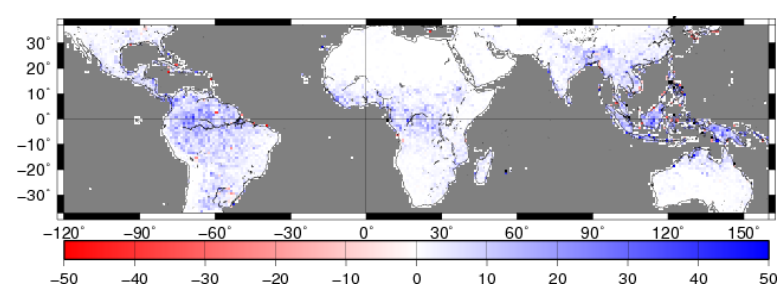

図-3 $50 \mathrm{~mm} / \mathrm{h}$ 以上の強い雨による寄与分の変化 $(\mathrm{V} 7-\mathrm{V} 6)$.

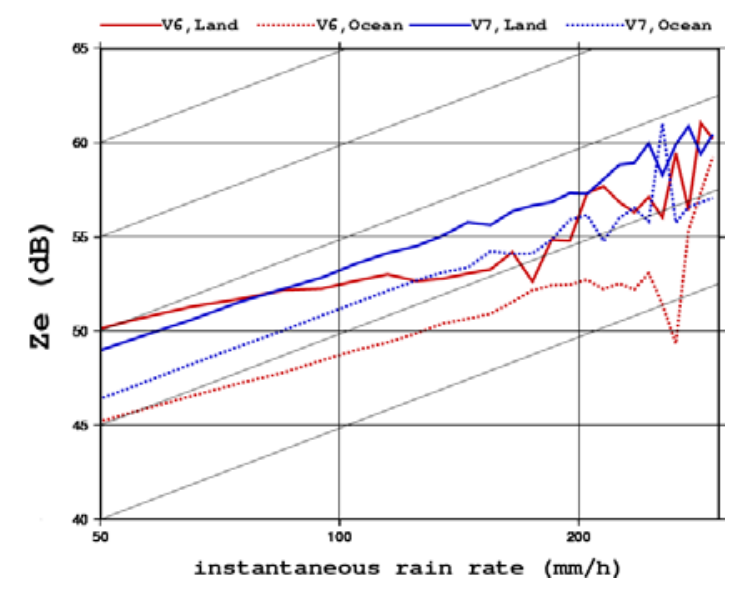

図-4 $50 \mathrm{~mm} / \mathrm{h}$ 以上の強い雨における地表面付近のZe $(\mathrm{dB})$. 横軸は降水強度を対数軸で示す (右端は $300 \mathrm{~mm} / \mathrm{h}$ ). 青 実線はV7陸上, 青点線はV7海上, 赤実線はVV6陸上, 赤点線はV6海上.

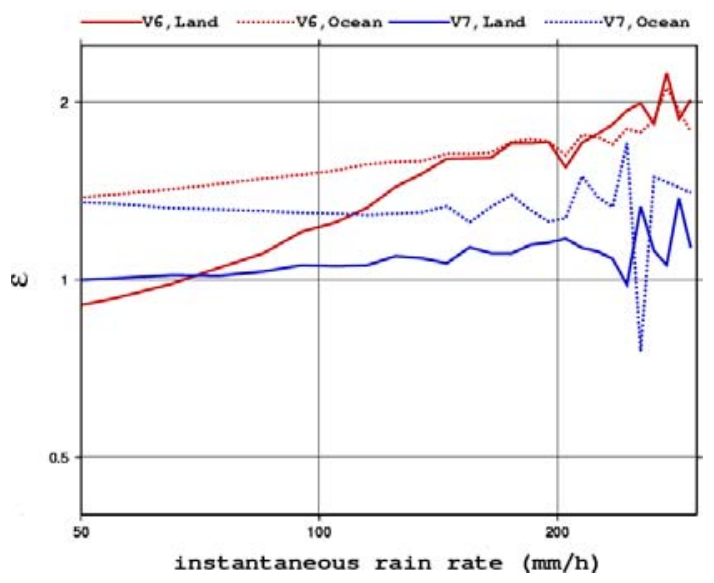

図-5 $50 \mathrm{~mm} / \mathrm{h}$ 以上の強い雨における $\varepsilon$. 横軸は降水強度を対 数軸で示す (右端は $300 \mathrm{~mm} / \mathrm{h}$ ). 青実線はV7陸上, 青点 線はV7海上, 赤実線はV6陸上, 赤点線はV6海上. 


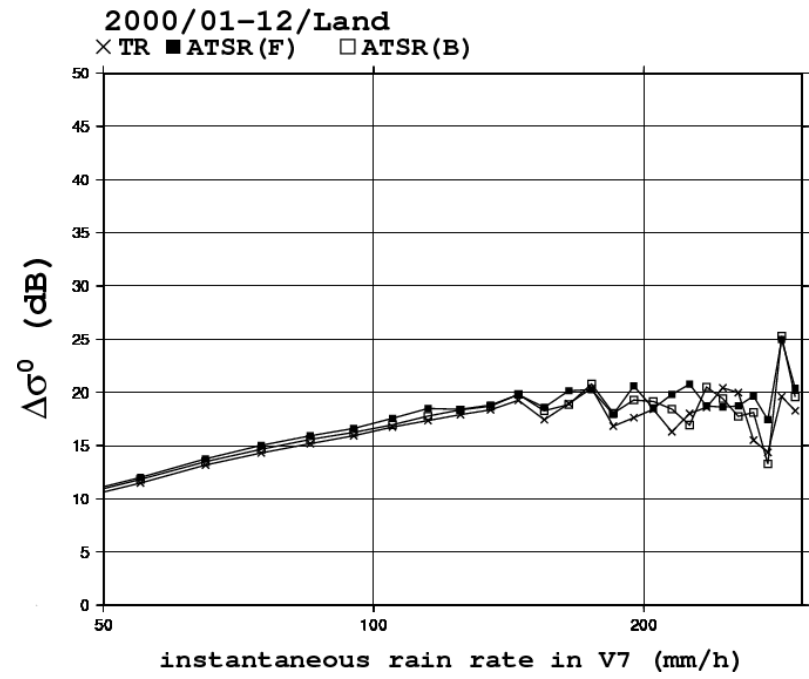

図-6 V7の強い雨に対する，各表面参照法による $\Delta \sigma^{0}$. 時 間参照法を×印，空間参照法(Forward処理)を印, 空間参照法(Backward処理) をロ印で示す.

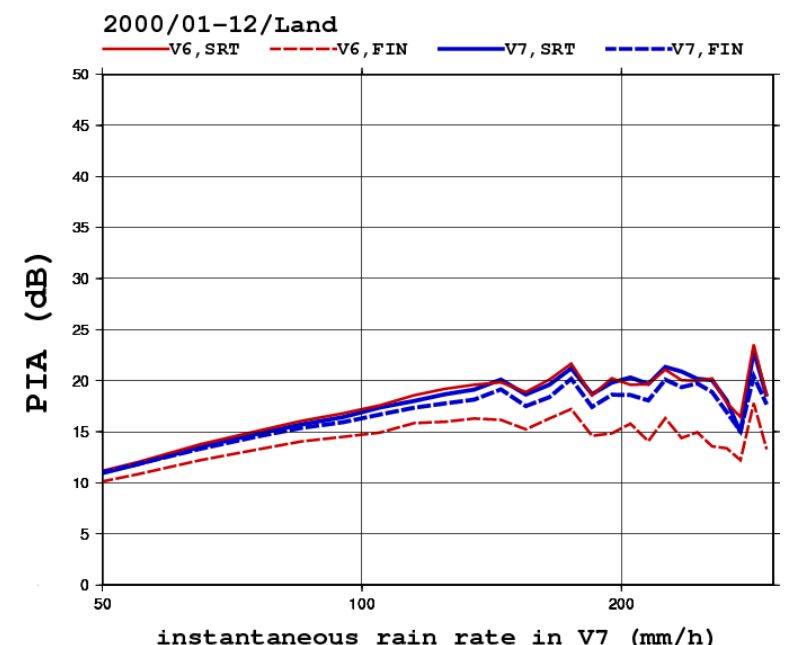

図-7 V7の強い雨に対するPIA推定値. V7第一推定値を青実 線, V7最終推定值を青鎖線, V6第一推定値を赤実 線，V6最終推定値を赤鎖線で示す.

は，表面参照法の信頼度を高く設定できるようになった ためと説明できる.

次に, V6での強い雨について, 同様の解析を図-8,

図-9に示す.V6でも使われている空間参照法(Forward処 理)が，他の2種類の手法に比べて高い $\Delta \sigma^{0}$ を示している. V6では，第一推定值は，空間参照法(Forward処理) $\Delta \Delta \sigma^{0}$ に強く依存しており，V7での第一推定值より高くなっ ている.この差が，PIAの最終推定值および降水強度推 定值にも影響しているとみられる.

図-3に示した沿岸域で強い雨がV6>V7となる現象は，こ れと似ており，表面参照法および最終的なPIA推定值も V6>V7となっている．沿岸域では，V6での時間参照法 においてデータベースが海陸の影響を十分区別できてい ない問題があり，V7ではこれが改良された効果もある とみられる。

以上のことから，強い雨における減衰補正の妥当性に

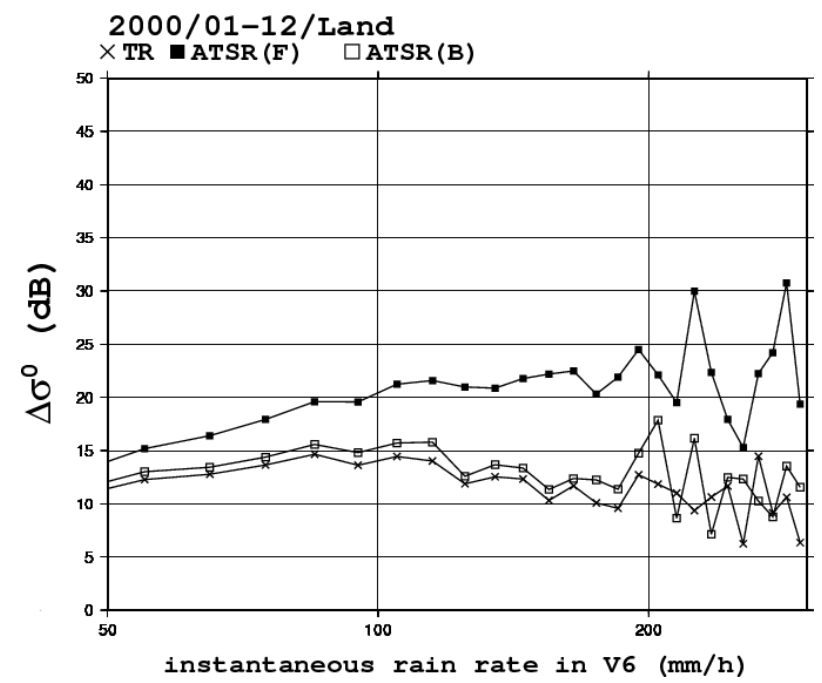

図-8 V6の強い雨に対する，各表面参照法による $\Delta \sigma^{0}$. 時

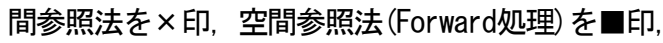
空間参照法 (Backward処理)を口印で示す.

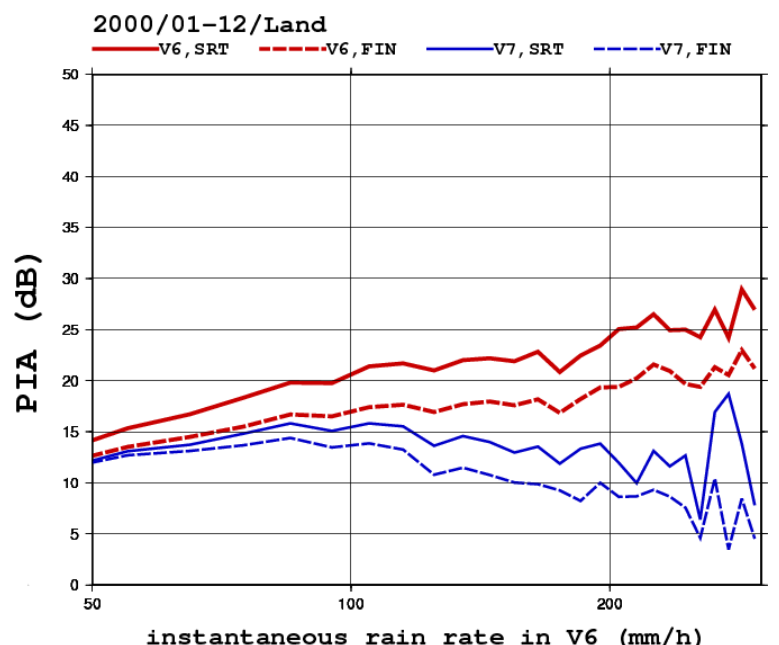

図-9 V6の強い雨に対するPIA推定値. V7第一推定值を青実

線, V7最終推定值を青鎖線, V6第一推定值を赤実

線，V6最終推定值を赤鎖線で示す。

関する考察をまとめると，V6での強い雨は，1種類の表 面参照法に強く依存しており，過大評価されている可能 性がある。一方，V7での強い雨は，3種類の表面参照法 で推定されているという点で，V6より信頼できる.

\section{(4) $300 \mathrm{~mm} / \mathrm{h}$ の雨}

先に述べたように，標準プロダクトでは $300 \mathrm{~mm} / \mathrm{h}$ を降 水強度の上限としている，これは，データサイズの都合 であるが，はたして300mm/h以上の強い雨は観測されな いのだろうか. 1時間降水量の世界最大值は $401 \mathrm{~mm} / \mathrm{h}$, 日本最大值は $187 \mathrm{~mm} / \mathrm{h}^{2}$ 報告されており ${ }^{15)}, 300 \mathrm{~mm} / \mathrm{h}$ を 超えることは極めて稀と言える。しかし，1章で述べた ように，PRで観測される降水強度の時間スケールは1時 間より短いと考えられる。例えば，1分降水量の世界最 大值は $38 \mathrm{~mm} / \mathrm{min}$ であり， $300 \mathrm{~mm} / \mathrm{h}$ に相当する $5 \mathrm{~mm} / \mathrm{min}$ をはるかに超えている. 


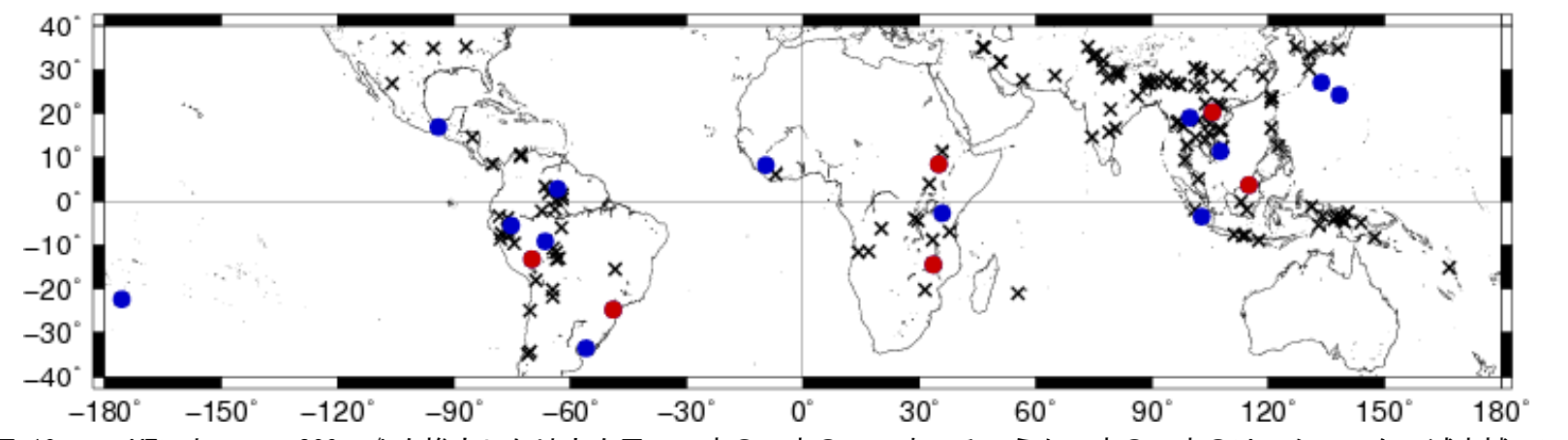

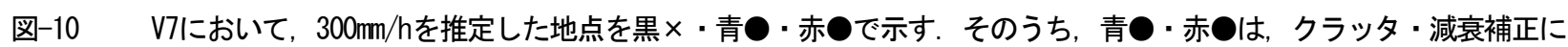
よる過大評価がないとみられるもの. 赤のは, $Z=200 R^{1.6}$ の関係式を用いても, $300 \mathrm{~mm} / \mathrm{h}$ 超えるもの.

V7で，2000年の1年間に，300mm/hが推定された場所 を図-10に示す。全部で154回あり，そのうち陸上が151 回，海上が3回であった。これに対して，V6では $300 \mathrm{~mm} / \mathrm{h}$ の推定值は陸上・海上ともにゼロであった.

V7で強い雨が増えている一般的な理由は，3章で説明 したが，特に強い雨の場合は，クラッタの誤判定が影響 している可能性がある．V7では，地表面によるクラッ タを降雨によるエコーから区別するための手法が変更さ れたが，より地表面近くまで雨をとらえられるように なったことの見返りに，クラッタを降雨エコーと誤判定 することがV6よりも増えていることが指摘されている16). そこで，V6とV7のマッチアップにより，V6では降雨が 観測されていないケース，および，V7でクラッタの推 定位置がV6より地表面に近くなっているケースを除外 した. その結果，92(陸上89, 海上3)回の300 mm/h推定值 が残った。

次に，減衰補正による過大評価の可能性があると疑わ れるケースをできるだけ除外する．表面参照法が3種類 揃っていないケース，および，3種類の表面参照法の $\Delta \sigma^{0}$ の最小值よりもPIAの最終推定值が大きいケースを 除外した結果，19(陸上16, 海上3)回の300 $\mathrm{mm} / \mathrm{h}$ の推定值 が残った.この19回については，特定の場所に集中する などの不自然な傾向は認められない.

最後に, Z-R関係の妥当性についての検証が必要だが,

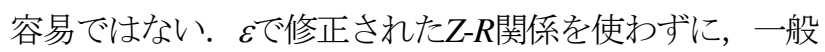
的な $Z=200 R^{1.6}$ を用いるならば， $R=300 \mathrm{~mm} / \mathrm{h}$ は $Z_{\mathrm{e}}=62.6 \mathrm{~dB}$

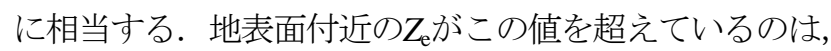
6回(いずれも陸上)であった。

\section{V7を用いた強い雨の特性に関する解析例}

本論文の最後に，V7を用いた強い雨の特性に関する 解析例として，地表面気温との関係について示す. 近年, 地球温暖化への関心を背景として，地表面気温と強い雨 の関係に関する考察が多く行われている ${ }^{17)}$. 強い雨の指 標として，地表面気温ビンごとの99\%(上位1\%)降水強度 を用いることが多い. 地表面気温の増加に対して，99\%
降水強度の増加割合が，飽和水蒸気圧の増加割合 (Clausius-Clapeyronの関係)とよく一致する例も報告され ている ${ }^{17)}$ ，その一方で地域性も強く ${ }^{18)}$, 熱帯域などでは, 気温の増加に対して，99\%降水強度は減少することも報

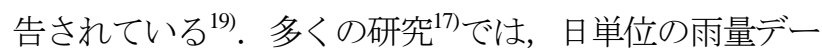
タを用いているが，アメダス10分データを用いて行った 研究19)では，南西諸島において，日降水量の99\%降水強 度は気温が約 $25^{\circ} \mathrm{C}$ を超えると減少するが，10分降水量や 時間降水量では99\%降水強度の減少は見られなかった。 このことは, 降水量データの時間スケールによる特性の 違いを示している.

GHCN(Global Historical Climatology Network)による日 降水量・日平均気温(日最高気温と日最低気温の平均)の 観測データがある緯度 $1^{\circ} \quad$ ×経度 $1^{\circ}$ グリッドについて, V7の降水強度推定值の日最大值および日平均值を抽出 した. また，GHCNの降水・気温データについては，グ リッドに観測点が複数ある場合, その平均を用いる.こ のようにして準備したデータを，GHCNの日平均気温に よりビン(平均して $2^{\circ} \mathrm{C}$ 幅, ただしビンごとのサンプル数 が一定となるようにする)に分類し，ビンごとにV7の降 水強度およびGHCNの日降水量の99\%值を求めた。デー タが利用可能な陸上の全域に対する結果を図-11に示す. GHCNの日降水量は， $25^{\circ} \mathrm{C}$ 付近をピークとして，それよ り気温が高い場合には減少しているが，V7の降水強度 には，そのような減少傾向は見られない。 これらのこと は，観測の時間スケールの違いを反映している.

\section{5. まとめ}

衛星観測される降水強度は，雨量計で観測される降水 量と異なった特性を持っている. PRで推定される降水 強度の時間スケールは, 数分から長くても1時間程度と 考えられる. 一般的に利用可能な雨量計のデータよりも， 短い時間スケールの降水強度情報を広域で利用できるこ とが，衛星観測の利点である.

PRの最新の標準プロダクトV7では，陸上において強 い雨が頻繁に推定されている. これらの強い雨は， $Z_{\mathrm{e}}$ が 


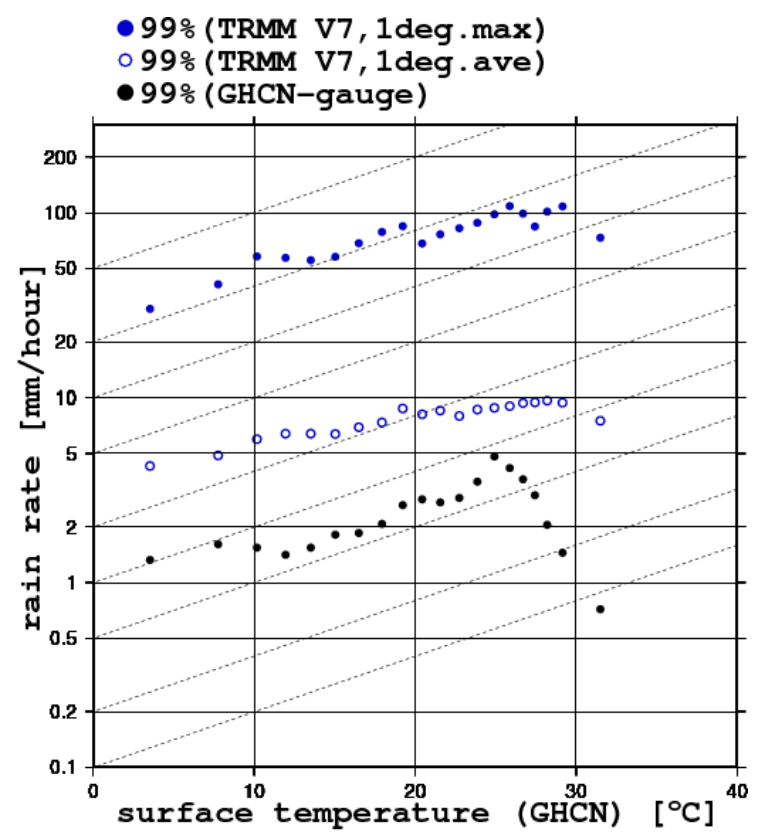

図-11 地表面気温と $99 \%$ 降水強度の関係. TRMMの $1^{\circ}$ グリッ

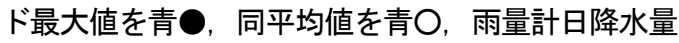
を黒○で示す.

高いことが主な要因であることが確認された．表面参照 法がV6に比べて大きく改善されており，減衰補正も妥 当に行われていると言える．Z-R関係の妥当性について はさらなる検討が必要であるが，少なくとも年間数例の ケースについては，300 mm/hを超える極めて強い雨が観 測された可能性がある。こうした強い雨について，観測 の時間スケールの定量化とあわせて検討する必要がある。

DPRではPR と同等の観測を継続するともに，二周波

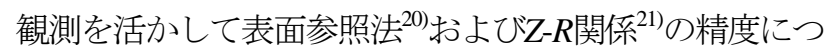
いても向上することが期待できる. 継続的なデータの蓄 積および精度向上により, 将来的には, 河川計画の基礎 となる計画降水量や，その気候変動影響の評価に，衛星 観測が大きな役割を果たす時代が来ること期待している.

謝辞 : 本研究は, 科学研究費補助金・若手研究(B)「水分野に おける実利用に適した衛星降水マップの作成(代表 : 瀬戸心 太)」およひ環境省環境研究総合推進費「温暖化影響評価・適 応政策に関する総合的研究」(課題番号S-8)の一部である.

\section{参考文献}

1) Iguchi, T., R. Meneghini, J. Awaka, T. Kozu, J. Kwiatkowki, N. Yoshida, S. Seto, and K. Okamato: Version 7 algorithm for the TRMM Precipitation Radar, $35^{\text {th }}$ Conference on Radar Meteorology, Pittsburgh, Sep. 2011.

2) 宇宙航空研究開発機構: 宇宙から見た雨2, P109, 2008.

3) Iguchi, T., T. Kozu, R. Meneghini, J. Awaka, and K Okamoto: Rain-profiling algorithm for the TRMM Precipitation Radar, $J$. Appl. Meteorol., Vol. 39, pp 2038-2052, 2000.

4) Meneghini, R., T. Iguchi, T. Kozu, L. Liao, K. Okamoto, J. A. Jones, and J. Kwiatkowski: Use of the surface reference technique for path attenuation estimates from the TRMM Precipitation Radar, J. Appl. Meteorol., Vol. 39, pp 2053-2070, 2000.
5) Hitschfeld, W., and J. Bordan: Errors inherent in the radar measurement of rainfall at attenuating wavelengths. J. Meteor., Vol. 11, pp58-67, 1954.

6) Kozu, T., T. Iguchi, T. Shimomai, N. Kashiwagi: Raindrop size distribution modeling from a statistical rain parameter relation and its application to the TRMM Precipitation Radar rain retrieval algorithm, J. Appl. Meteorol. Clim., Vol. 48, pp716-724, 2009.

7) Kozu, T., T. Iguchi, T. Kubota, N. Yoshida, S. Seto, J. Kwiatkowski, Y. N. Takayabu: Feasibility of raindrop size distribution parameter estimation with TRMM Precipitation Radar, J. Meteor. Soc. Japan, Vol. 87A, pp53-66, 2009.

8) Iguchi, T., T. Kozu, J. Kwiatkowski, R. Meneghini, J. Awaka, and K. Okamoto: Uncertainties in the Rain Profiling Algorithm for the TRMM Precipitation Radar, J. Meteor. Soc. Japan, Vol. 87A, pp130, 2009.

9) Shige, S., H. Sasaki, K. Okamoto, and T. Iguchi: Validation of rainfall estimates from the TRMM precipitation radar and microwave imager using a radiative transfer model: 1 . Comparison of the version-5 and -6 products, Geo. Res. Let., Vol. 33 doi:10.1029/2006GL02630, 2006.

10) Kawamoto, N., R. Oki, S. Shimizu: Comparison between TRMM/PR and AMeDAS rain gauge network in terms of annual rainfall, IGARSS, Vancouver, July 2011.

11) Meneghini, R., J. A. Jones, T. Iguchi, K. Okamoto, and J. Kwiatkowski: A hybrid surface reference technique and its application to the TRMM Precipitation Radar, J. Atmos. Ocean. Technol., Vol. 21, pp1645-1658, 2004.

12) Seto, S., and T. Iguchi: Rainfall-induced changes in actual surface backscattering cross sections and effects on rain -rate estimates by spaceborne precipitation radar, J. Atmos. Ocean. Technol., Vol. 24, pp1693-1709, 2007.

13) Seto, S., T. Oki, and T. Iguchi: Evaluation and improvement of surface reference techniques for the TRMM PR, IGARSS, Boston, July 2008.

14) Seto, S., and T. Iguchi: Comparison of TRMM PR V6 and V7 focusing heavy rainfall, IGARSS, Vancouver, July 2011.

15) 木口雅司，沖大幹 : 世界・日本における雨量極值記録，水 文・水資源学会誌，第23巻，pp231-247，2010.

16) 濱田篤, 高薮縁 : TRMM V7_2A25データのextreme rain值に 対するフィルタの作成, 日本気象学会秋季大会, 名古屋, 2011.

17) Allan, R. P., and B. J. Soden: Atmospheric warming and the amplification of precipitation extremes, Science, Vol. 321, pp14811484, 2008

18) Lenderink, G., and E. van Meijgaard: Increase in hourly precipitation extremes beyond expectations from temperature changes, Nature Geoscience, Vol. 1, pp511-514, 2008.

19) Utsumi, N., S. Seto, S. Kanae, E. Maeda, T. Oki: Does higher surface air temperature intensify extreme precipitation?, Geo. Res. Let., Vol. 38, L16708, doi:10.1029/2011GL048426..

20) Meneghini, R., L. Liao, S. Tanelli, and S. L. Durden: Investigation of a dual-frequency surface reference technique for estimates of path-integrated attenuation, Conference on Radar Meteorology, Pittsburgh, Sep. 2011.

21) Seto, S., and T. Iguchi: Applicability of the iterative backward retrieval method for the GPM Dual-frequency Precipitation Radar, IEEE. Trans. Geosci. Remote Sensing, Vol. 49, pp 1827-1838, 2011.

(2011. 9. 30 受付) 